\title{
The collaboration between governments and civil society organizations in response to emergency situations
}

\author{
Mário Aquino Alves 1 \\ Marcelo Marchesini da Costa ${ }^{2}$ \\ 1 Fundação Getulio Vargas / São Paulo School of Business Administration, São Paulo / SP - Brazil \\ 2 Insper Instituto de Ensino e Pesquisa, São Paulo / SP - Brazil
}

\begin{abstract}
The COVID-19 pandemic is an example of a large-scale emergency that defies public administration. There is a variety of large-scale emergency events, and the government is responsible for responding to such situations. Civil Society Organizations (CSOs) can contribute to a fast and appropriate response to these emergencies. This article discusses the characteristics of CSOs that qualify them to contribute to the government's emergency responses. We also analyze possible collaborative arrangements between governments and CSOs.
\end{abstract}

Keywords: COVID-19; civil society organizations; emergency; collaboration.

\section{Colaboração entre governos e organizações da sociedade civil em resposta a situações de emergência}

A pandemia da COVID-19 é um exemplo de grande emergência que desafia a administração pública ocasionalmente. A despeito da variedade de eventos dessa natureza, recai sobre o governo, majoritariamente, a responsabilidade pelas ações emergenciais nesses momentos. Organizações da Sociedade Civil (OSCs) podem, no entanto, contribuir para uma resposta rápida e adequada a tais ocorrências. Neste artigo, são discutidas as características das OSCs que as habilitam a contribuir para as medidas de emergência adotadas pelos governos. Analisa-se também a possibilidade de ampliação dos arranjos colaborativos entre governos e OSCs.

Palavras-chave: COVID-19; organizações da sociedade civil; emergência; colaboração.

\section{Colaboración entre gobiernos y organizaciones de la sociedad civil en respuesta a situaciones de emergencia}

La pandemia de COVID-19 es un ejemplo de gran emergencia que ocasionalmente desafía a la administración pública. A pesar de la variedad de eventos de esa naturaleza, el gobierno es el principal responsable de las acciones de emergencia en esos momentos. Sin embargo, las organizaciones de la sociedad civil (OSC) pueden contribuir a una respuesta rápida y adecuada a estas emergencias. Este artículo analiza las características de las OSC que las califican para contribuir a las medidas de emergencia adoptadas por los gobiernos. También se analiza la posibilidad de ampliación de los acuerdos de colaboración entre gobiernos y OSC.

Palabras clave: COVID-19; organizaciones de la sociedad civil; emergencia; colaboración. 


\section{INTRODUCTION}

Disasters and major emergencies, such as extreme weather phenomena, terrorist attacks and epidemics, require rapid action in order to preserve lives, limit damage and enable the crisis to be quickly overcome. Different levels of government are usually expected to provide this response. It is natural and correct that this is the way it should be, as government is primarily responsible for safeguarding public interests. It is not, however, feasible for government to always have a structure at its disposal that is only necessary in times of major disaster. The global crisis generated by COVID-19 is a clear example of this: facing up to the pandemic requires countless hospital beds and large amounts of equipment that would otherwise be superfluous in normal times.

One possible alternative way of immediately responding to challenges of this kind is to take advantage of the private sector's infrastructure, human resources and processes. A crisis like COVID-19, however, also poses enormous challenges when it comes to achieving the economic objectives and ensuring the sustainability of companies. There is also an important group of civil society organizations, CSOs, whose social function becomes very evident in times of great public commotion. There have been various examples of the spontaneous mobilization of civil society for minimizing the damage from COVID-19, and this response could be expanded with the support and coordination of government.

The aim of this work is to indicate how governments at all levels can take advantage of CSOs for improving their responses to different types of emergency. In this article we discuss how the response to a major emergency requires governments to play a central role, but there are great opportunities for gains in scale and scope in this response by way of partnerships and collaboration with civil society.

We initially present the current context of CSOs in Brazil and then briefly discuss theories of intersectoral relations. In the subsequent section we analyze the context of major emergencies. Finally, we set out our recommendations for actions and policies in this context and present our conclusions.

\section{THE CONTEXT OF CIVIL SOCIETY ORGANIZATIONS IN BRAZIL}

The context of CSOs in Brazil is presented on the basis of some of their central dimensions, namely their financial, institutional, managerial and political. From a financial perspective, there has been a large reduction in resources emanating from international cooperation and destined for Brazilian CSOs since the early 2000s (Marchesini da Costa, 2019). The advance of the governments that were elected at various levels in 2018 and whose discourse is hostile to CSOs undermines the continuity of government funding programs for these organizations. Funding restrictions for CSOs, a process that has been going on for almost ten years since the beginning of the 21st century, is frequently accompanied by a distrust of the seriousness of their activities (Mendonça, Alves, \& Nogueira, 2016).

The design of regulations governing CSOs in Brazil plays a central role institutionally. The regulation of CSOs is understood to be the State's passing of primary legislation (the constitution and laws) or secondary legislation (ordinances, normative instructions, administrative decisions), and the sector's own contributions and self-regulatory mechanisms (Breen, Dunn, \& Sidel, 2019). Although there was an advance from the regulation viewpoint when the Regulatory Framework for Civil Society Organizations (MROSC) was approved in the middle of the last decade (Appe \& 
Marchesini da Costa, 2016), the government's control ecosystem (which comprises both the accounting courts, court disciplinary boards, and even the Public Prosecution Office $[M P]$ ) does not separate the misuse of public funds from problems related to difficulties with accountability, and this leads to the criminalization of all CSOs (Souza \& Oliveira, 2020). Regulation of the partnerships between CSOs and the State in Brazil also focuses heavily on language and practices that are conceived from the viewpoint of the State, which implies that there is little mutual trust between the agents (Peci, Oquendo, \& Mendonça, 2018).

The managerial aspect highlights certain weaknesses that CSOs suffer from. As a rule, both in Brazil and internationally, CSOs have no specific management skills for fundraising or institutional development (Armani, 2008; Bish \& Becker, 2016). Most of them minimize the relevance of good management, even though one influential group of third sector organizations that are generally linked to foundations or business groups - corporate philanthropy, stands out by adopting excellent management tools (Marchesini da Costa, 2019). Corporate philanthropy, however, which is concerned with private social investment in Brazil, concentrates its resources on its own projects that are in line with corporate strategies and often unrelated to the agendas of other Brazilian CSOs (GVceapg \& Articulação D3, 2013; Pagotto, Belinky, Macedo, \& Yamahaki, 2016). In any case, good management practices need to be disseminated among Brazilian CSOs.

Finally, it is important to note that the current political climate in Brazil, where predominantly conservative thinking is hostile towards CSOs, especially towards those that deal with human rights, makes it difficult for the average citizen to approach these organizations, whether as a volunteer or to donate resources (Abdal et al., 2019; Alves, Nogueira, Pineda, \& Campos, 2019). This political moment in time is likely to affect Brazilian CSOs in different ways, particularly because of the sector's own diversity. Religious organizations, for example, which constitute $35 \%$ of the CSOs in Brazil, tend to be affected differently, depending on whether the organization is linked to a progressive or a conservative line, as does the $12 \%$ of CSOs that are formed by professional associations (Brazilian Institute of Geography \& Statistics [IBGE], 2016).

Despite these difficulties and limitations, there has been an increase in the number of CSOs in recent decades; there were approximately 780,000 organizations in April 2020 (Economic Institute of Applied Research [IPEA], 2020). CSOs can be found in thousands of municipalities, but many of them operate in and benefit a wider region, and also form networks with other organizations (Marchesini da Costa, 2017). It is worth remembering that a large part of Brazil's CSOs are religious organizations, and therefore play an important role in the community (Marchesini da Costa, 2017). Finally, although the services provided by these organizations and their missions are diverse, many focus on social activities, such as social development, social welfare and health (Ipea, 2020; Marchesini da Costa, 2017), which indicates their potential for contributing precisely to those issues that are relevant for confronting the coronavirus pandemic.

Before discussing in more depth the participation of CSOs in responding to major emergencies, the next section provides relevant information about the origin of CSOs and the relationship they have with the State. 


\section{INTERSECTORAL RELATIONSHIPS}

The term intersectoral commonly refers to an initiative that is of interest to different sectoral policies, such as youth policies, for example (Marcondes, Sandim, \& Diniz, 2018). In this article, however, the concept is used in the sense of relations between different sectors of the economy; more specifically relations between the State and the third sector ${ }^{1}$. Some authors (Weisbrod, 1978) understand that civil society organizations emerge from market failure in order to satisfy the demand for public goods, in other words, for goods that should be democratically made available, whether free of charge or not. In the classic model, this market failure creates the conditions necessary for the government to intervene and offer public goods (Lecy \& Van Slyke, 2012; Smith \& Lipsky, 1993; Young, 2000). In democracies, where there is a large number of diverging opinions on which public goods should be produced and offered, and only the opinion of the average voter is considered, there would be demand niches that would not be satisfied by a government failure (Smith \& Lipsky, 1993; Weisbrod, 1978). Under such conditions, civil society is mobilized to produce and offer public services that cannot be guaranteed by either the market or by government. (Steinberg, 2003; Weisbrod, 1978).

Whereas market failure and government failure theories emphasize the unmet demand for public goods, other theories examine supply failure (James, 1990; Steinberg, 2003). Taking the idea that there is unmet demand for public goods that is necessary but not sufficient, the supply failure theory emphasizes that some individual or collective agents would be encouraged to create non-profit organizations to meet such a demand, which would give rise to a group of "social entrepreneurs" (James, 1990). For example, where more than one religion has an influence, the conditions are created for "religious competition" for new followers (Salamon \& Anheier, 1998). In this competition for new believers, congregations create goods and services, for example, such as providing education and social and medical assistance (James, 1990; Salamon \& Anheier, 1998).

The theoretical models shown above start from a basic premise: the existence of civil society organizations depends, among other things, on the absence (or inefficiency) of the State, and a market that meet people's needs in economic terms; in other words, those markets and governments that effectively meet the demands of society could dispense with the existence of a private non-profit sector. Following this logic, some theories understand the existence of civil society (or the third sector) as a residual form of the existence of the State, or as a complementary element in the regulation of the capitalist order (Abzug \& Webb, 1999). General literature on the welfare state, for example, pays little attention to the issue of civil society or the third sector (Salamon \& Anheier, 1998). At most, civil society is treated as a set of pre-modern social welfare institutions that, like families, religious organizations and other organizational forms of charity, lost their main welfare function with the development of capitalism (Flora \& Heidenheimer, 1981). From this point of view, archaic social institutions would be unable to meet the social provision required of them, and would cause a type of State to emerge that would undertake this type of provision (Offe, 1984). For this reason, some societies developed no more than a "residual" welfare state, since they restricted much of their social provision to its archaic institutional forms (Titmuss, 1974).

Whereas more classic theories on the welfare state tend to treat civil society in a residual way, or as comprising archaic institutions that lost their meaning with the advent of capitalism, this scenario has

\footnotetext{
${ }^{1}$ Like Alves (2004), we assume here that the "third sector" is a part of civil society, but a part that provides services.
} 
recently changed. Maybe due to the crisis in the social welfare state, which seems to no longer meet the needs for public goods, many researchers have started considering civil society as organizations and institutions that are on a par with the market and with the State when it comes to producing goods and services for public enjoyment. According to Lester Salamon (1987), both economic and regulatory views start from a paradigm of conflict between the State and civil society (see Najam, 2000). In other words, the various authors can only perceive spaces of conflict and competition between state and non-profit sectors. Salamon (1987), however, argues that partnership and interdependence tendencies between the State and civil society also emerge at the same time as conflicting spheres; in fact, interdependence is more common than conflict.

CSOs are usually more agile than government in the social field, and their potential for political mobilization works as a stimulus for state action and simultaneously includes them in the process of providing goods and services (Boris, 2006; Frumkin, 2002). CSOs, however, have inherent limitations voluntary failure being one - when it comes to meeting the demand for public goods, mainly with regard to the generation of funds for supporting their activities and, in many cases because of their paternalistic forms of management, in which there are difficulties in promoting broader social policies (Salamon, 1995). This is why, according to Salamon (1995), civil society and the State create cooperation possibilities to solve certain social problems. These possible relations depend on several factors, in particular those of an ideological nature; because of political pressure, the State sometimes fails to intervene directly in the supply of a certain public good and delegates its provision to CSOs. The view of certain sectors is that such organizations have greater political legitimacy for providing these services.

Some of the theories about cooperation between the State and civil society (Najam, 2000; Salamon, 1987; Young, 2000) consider that, unlike what economics teaches, or even the more traditional view of the welfare state, the larger the State's field of action, the greater the possibility of the development of civil society (Abzug \& Webb, 1999; Salamon \& Anheier, 1998), with the State functioning as the biggest financier of its activities. In fact, partnerships between CSOs and government in Brazil are broad and their results vary, according to the type of organization and the region of the country in which they operate (Marchesini da Costa, 2017). Among other relevant results, specific examples indicate that better structured CSOs are capable of putting forward action proposals to local governments (Ribeiro, Andion, \& Burigo, 2015), and that they play an important role in improving democracy by monitoring government actions (Moreira, Teodósio, \& Ayres, 2020). Social organizations provide a large part of the services in Brazil's biggest municipalities, particularly in the health area.

Having introduced civil society and third sector organizations, we now need to understand the role played by CSOs in responding to major emergencies.

\section{THE SPECIFICS OF MAJOR EMERGENCIES AND COLLABORATIVE GOVERNANCE ARRANGEMENTS}

Emergencies, like automobile accidents and small fires, occur every day. There are public organizations that focus primarily on dealing with these situations, such as the Fire Department and Civil Defense ${ }^{2}$. Major emergencies, however, differ in scale and create a specific context to which organizations and the

\footnotetext{
${ }^{2}$ In various countries, the fire brigade and civil defense are civil society organizations that are strongly supported by the State.
} 
usual processes are unable to adapt (Henderson, 2014). Several authors have stressed the importance of collaboration between different sectors for responding to major emergencies of various types, from terrorist attacks (Comfort \& Kapucu, 2006) to natural disasters (Simo \& Bies, 2007). Studies in the United States indicate that the Red Cross and the Salvation Army are the main sources of assistance for disaster victims in that country (Waugh \& Streib, 2006). In times of emergency, public managers must be prepared to take advantage of the financial, administrative and political resources that the network of non-governmental partners can offer in response to the situation (Waugh \& Sylves, 2002).

The first challenge posed by a major emergency is to quickly mobilize this network of potential civil society partners to assist in the actions. Countless examples indicate that, either with or without government coordination, the third sector tends to mobilize to respond to major emergencies. Shortly after the start of the COVID-19 pandemic, the Institutes, Foundations and Companies Group (GIFE), which represents institutionalized philanthropy in Brazil, developed its "COVID-19 Emergency" platform to support civil society projects and provide help in facing up to the pandemic (https://emergenciacovid19.gife.org.br/); and the Brazilian Association of Non-Governmental Organizations (Abong), which represents some of the human rights defense CSOs, launched the "Solidarity Network" (https://www.redesolidaria.org.br/), which handles civic engagement actions, donations and advocacy. At the same time, new undertakings have also emerged as an emergency rapid response to the pandemic, such as the Slums against Coronavirus project (https://www.facebook. com/favelascontraocoronavirus), or community mobilizations in Paraisópolis, in the city of São Paulo. Box 1 lists only a small number of these initiatives, in order to show the breadth and variety of their focuses.

BOX 1 EXAMPLE OF CSO INITIATIVES IN BRAZIL AS A RESPONSE TO THE COVID-19 PANDEMIC

\begin{tabular}{|c|c|}
\hline CSO & Brief description of the initiative \\
\hline Slum Central Office (CUFA) & $\begin{array}{l}\text { Income supplement of } \mathrm{R} \$ 120 \text { for women with children living in communities during } \\
\text { the pandemic. }\end{array}$ \\
\hline Médecin sans Frontières (MSF) & Medical help for the most vulnerable. \\
\hline Citizenship Action & Food donations. \\
\hline Franciscan Solidarity Service (Sefras) & Donation of protection and personal hygiene equipment. \\
\hline $\begin{array}{l}\text { Linking the Indigenous Peoples of } \\
\text { Brazil (APIB) }\end{array}$ & Donations of food, medication and hygiene materials for Brazilian Indian villages. \\
\hline $\begin{array}{l}\text { The Enfrente (Ahead) Platform } \\
\text { (various CSOS) }\end{array}$ & $\begin{array}{l}\text { A match-funding initiative (the fund adds } \mathrm{R} \$ 2 \text { for every } \mathrm{R} \$ 1 \text { donated) with hundreds } \\
\text { of participating projects. }\end{array}$ \\
\hline Comunitas & Donation of equipment, such as respirators for hospitals in the public network. \\
\hline
\end{tabular}

Source: Elaborated by the authors based on research into the websites of organizations. 
Box 1 highlights initiatives that have little or no collaboration from the State. It is appropriate, therefore, to indicate how collaborative actions can be implemented in emergency situations.

A mix of formal mechanisms, such as partnership terms and contracts, and informal mechanisms, such as personal relationships and informal agreements, can be used to accommodate all potential partners (Waugh \& Sylves, 2002). Studies into collaborative governance analyze those aspects that make intersectoral arrangements more agile. We highlight, for example, the need for a clear common objective, a suitable regulatory framework, good experiences with pre-existing relationships and committed leaders (Bryson, Crosby, \& Stone, 2015; Shaw \& Goda, 2004).

The rapid mobilization of efforts, however, may not be the greatest challenge. Not every collaboration leads to positive results (O'Donovan, 2019). A shelter for the homeless that is run by a CSO and that speeds up the spread of COVID-19, for example, would be part of the problem rather than the solution. What is needed are structure, processes and, above all, initial effective communication between partners (Bryson et al., 2015), as is clarification regarding actions that can help with the response to an emergency situation. Public investment is essential for making a communication strategy feasible that reinforces and clarifies this common objective (Comfort \& Kapucu, 2006).

Finally we emphasize that in disaster or crisis situations, immediate actions by the State are important in order to guarantee the institutional and financial sustainability of civil society itself (Shaw \& Goda, 2004). This is necessary not only to guarantee the extensive care capacity of CSOs over the long term, (Shaw \& Goda, 2004), but also to maintain mutual trust in the communities (Tilly, 2008) and in the democratic regime itself (Lin, 2015).

\section{ACTION AND POLICY RECOMMENDATIONS}

Based on the arguments presented above, we now highlight some of our proposals for public actions and policies that can be implemented by governments at different levels. We also stress that the following measures are general aspects of a response strategy to major emergencies, and may assist in responding to the COVID-19 pandemic and other such major events. Different types of emergency, of course, such as a pandemic, a major flood or a large fire, have their own peculiarities, but these are not considered here. The proposition refers to the basic and, therefore, general care that should be considered by governments in any situation in order to make the best use of the capacity of CSOs.

\section{1) Government leaders who are committed to good intersectoral relationships}

Collaborative governance models emphasize the importance of good pre-existing relationships between different actors in order for collaboration to be successful (Bryson et al., 2015). Those actions and statements that demonstrate the distrust and animosity of government leaders towards CSOs generate resistance on the part of the latter when it comes to collaborating with the government. The government needs to maintain a constant dialogue and recognize the importance of CSOs in the communities in which they operate. Civil society has put forward excellent proposals for tackling the COVID-19 pandemic, such as 'Quarantine Rooms', as suggested by the CSO, Minha Sampa (https:// www.quartosdaquarentena.minhasampa.org.br/), which suggests using hotels as temporary shelters for the homeless or other vulnerable segments of the population during the pandemic. For this to function, 
it is essential that the example and direction of government leaders is unequivocal in recognizing the importance of CSOs. There is no point in having a committed technical and bureaucratic body if it is not backed up by the discourse and actions of the government's political leaders.

\section{2) Making processes and controls flexible}

The diversity of CSOs implies that many organizations have little institutional capacity, and in some there is even the possibility of funds being misapplied/embezzled of funds (Ebrahim, 2003; Smillie, 1995). Governments that have experience of partnerships with CSOs have information that allows them to differentiate and exclude these cases, especially when there are already established and customary spaces for dialogue, like councils (Mendonça, Medeiros, \& Araújo, 2019). Times of major emergency, however, are not conducive to the usual procedures for hiring and controlling partners being applied. In a recent study, Souza \& Oliveira (2020) show that responding to the usual control procedures, such as Siconv (now Plataforma+Brasil), is still a challenge for many CSOs. Collaboration combined with security needs to be quickly triggered so that the partners can act without fear of being held responsible because of details in the control rules (Mendonça et al., 2019). For this to happen, the priorities during the crisis and when activities resume need to be made absolutely clear (Blanco, 2015).

\section{3) Transparency and open government}

Transparency and government opennessare prerequisites in major emergency situations. Care must be taken, however, to ensure that the actions initiated in response to the situation fit in with and strengthen existing government mechanisms. For example, making bureaucratic control more flexible for emergency measures does not mean not making information about purchases and contracts readily available on public procurement portals. This makes accountability possible and allows any misuse and/or failure that might compromise the legitimacy of the response to a major emergency to be identified.

\section{4) Effective communication}

The government's first and most important act for making the civil society actions that help in the response to major emergencies feasible might be to establish communication channels that are: fast, constantly updated, clear, easily accessible and carry convergent messages. Any difficulty in accessing official information, or the lack of government communication that is genuinely two-way and that allows correct information to be identified, can generate feelings of anger and disbelief in society and mobilize it for confrontation (Kang, Kim, \& Cha, 2018). This also discourages collaboration on the part of CSOs, or triggers actions that hinder any response and makes the latter difficult.

\section{5) Strengthening the actions of public policy councils}

Governance arrangements go beyond collaboration for implementing public policies. The constant relationship between government agents and CSO representatives on public policy councils can help build trust and positive ties between these actors. In order to achieve this, however, councils need 
to function effectively, with regular meetings, the democratic conduct of the same, and with regard to the choice of members and the respectful debate of relevant matters. Councils are very different and vary because of the sectoral policies they represent and their contexts (Buvinich, 2014), with municipal councils tending to be more democratic than national councils (Gomes, 2015). Even so, the guarantee of effective two-way communication with society involves councils being activated, especially in times of crisis (Kang et al., 2018), and thereby contributing towards ensuring that any deliberations are of a more democratic nature (Gomes, 2015).

\section{6) Focused grants of institutional philanthropy (business and family foundations and institutes) for ex- panding the capacity of CSOs}

With regard to the philanthropic actions that have been organized in Brazil as a result of the COVID-19 pandemic, such as emergency donations ${ }^{3}$, it is clear that efforts have focused on mitigating the effects of the pandemic in vulnerable areas and on strengthening the capacity of CSOs to act in their own communities. Institutional philanthropy, therefore, faces the challenge of issuing specific terms of reference for recuperating the institutional capacity of CSOs in order to promote their sustainability and community development.

\section{CONCLUSION}

This article looks at how CSOs can mobilize relevant human and organizational resources in their response to major emergencies. The scope, specific knowledge and orientation of social and humanitarian missions can facilitate and boost actions in their response to problems caused by the COVID-19 pandemic. Studies of intersectoral collaborative arrangements indicate that this potential, which is used worldwide in normal times, can also be mobilized in the event of major emergencies.

Emergency situations can encourage and forge new relationships between governments and CSOs, thereby generating opportunities for contact and bonds of trust between these parties. The quality of the response, however, largely depends on actions and policies prior to these events. Good use of the capacity of CSOs for supporting emergency actions depends on the relationship conditions between government, CSOs and society. These actions become weak if they are not jointly implemented. Figure 1 shows the interaction that exists between the actions and policies that are suggested in this work.

\footnotetext{
${ }^{3}$ By the time we had finished this version of the article (May 16, 2020), the ABCR's COVID-19 Donation Monitor (https://www. monitordasdoacoes.org.br/) was indicating that $\mathrm{R} \$ 4,873,927,567.00$ had been received for fighting the epidemic, most coming from institutional philanthropy. Almost all the donations were made to governments or private or public healthcare organizations by way of financial resources or in-kind.
} 


\section{FIGURE 1 POLICIES AND ACTIONS IN COLLABORATION WITH CSOS AS A RESPONSE TO EMERGENCIES}

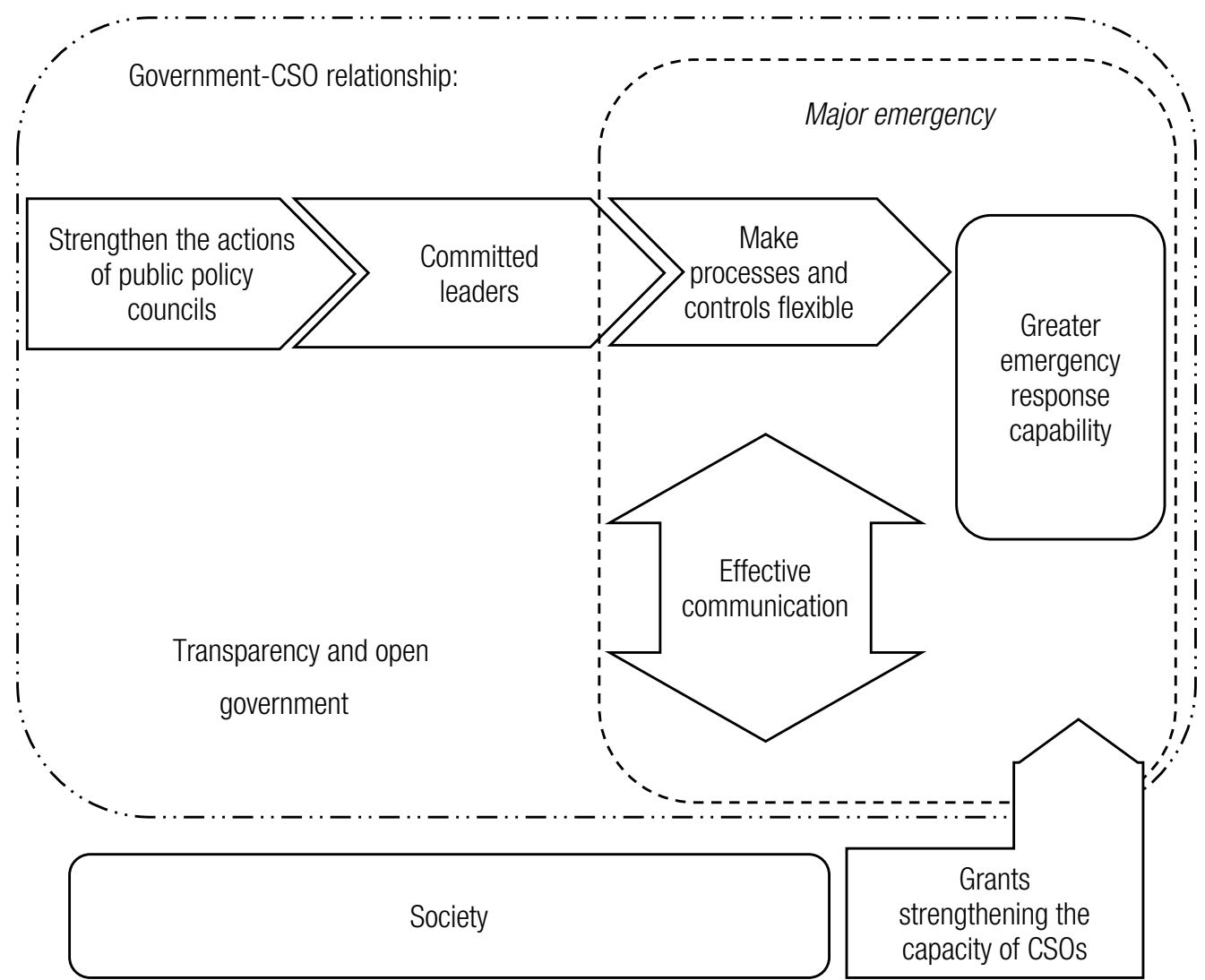

Source: Elaborated by the authors

A collaborative arrangement between governments and CSOs would not only expand the service provision and response network in the event of major emergencies, but could improve the policies and actions that are adopted. 


\section{REFERENCES}

Abdal, A., Alves, M. A., Nogueira, F. A., Pineda, A., Campos, P. H., Calixto, G., \& Campos, G. (2019). Pesquisa Comportamental sobre Doadores de Alta Renda. São Paulo, SP: Conectas e CEAPG.

Abzug, R., \& Webb, N. J. (1999). Relationships between nonprofit and for-profit organizations: a stakeholder perspective. Nonprofit and Voluntary Sector Quarterly, 28(4), 416-431.

Alves, M. A. (2004). O conceito de sociedade civil: em busca de uma repolitização. Organização $e$ Sociedade, 11, 141-154.

Alves, M. A., Nogueira, F. A., Pineda, A., \& Campos, P. H. (2019, May). Doadores de Alta Renda e Organizações de Direitos Humanos no Brasil. In Anais do $8^{\circ}$ Encontro de Administração Pública da ANPAD, Fortaleza, CE. Retrieved from http://www.anpad. org.br/eventos.php?cod_evento=6\&cod_edicao_ subsecao $=1650 \&$ cod_evento_edicao $=94 \& \operatorname{cod}$ _ edicao_trabalho $=26147$

Appe, S., \& Marchesini da Costa, M. (2016). Waves of Nonprofit Regulation and Self-Regulation in Latin America: Evidence and Trends from Brazil and Ecuador. In O. B. Breen, A. Dunn, \& M. Sidel (Eds.), Regulatory Waves Comparative Perspectives on State Regulation and Self-Regulation Policies in the Nonprofit Sector (pp. 154-175). Cambridge, UK: Cambridge University Press.

Armani, D. (2008). Mobilizar para transformar: a mobilização de recursos nas organizações da sociedade civil. São Paulo, SP: Editora Peirópolis.

Bish, A., \& Becker, K. (2016). Exploring expectations of nonprofit management capabilities. Nonprofit and Voluntary Sector Quarterly, 45(3), 437-457.

Blanco, D. V. (2015). Disaster governance in the Philippines: Issues, lessons learned, and future directions in the post-Yolanda super typhoon aftermath. International Journal of Public Administration, 38(10), 743-756.

Boris, E. T. (2006). Nonprofit Organizations in a Democracy: Varied Roles and Responsibilities. In E. T. Boris, \& C. E. Steuerle (Eds.), Nonprofits \& Government: Collaboration and Conflict (2nd ed., pp. 1-36). Washington, DC: Urban Institute.

Breen, O. B., Dunn, A., \& Sidel, M. (2019). Riding the regulatory wave: reflections on recent explorations of the statutory and nonstatutory nonprofit regulatory cycles in 16 jurisdictions. Nonprofit and Voluntary Sector Quarterly, 48(4), 691-715.

Bryson, J. M., Crosby, B. C., \& Stone, M. M. (2015). Designing and implementing cross-sector collaborations: needed and challenging. Public Administration Review, 75(5), 647-663.

Buvinich, D. P. R. (2014). O mapeamento da institucionalização dos conselhos gestores de políticas públicas nos municípios brasileiros. Revista de Administração Pública, 48(1), 55-82.

Comfort, L. K., \& Kapucu, N. (2006). Interorganizational coordination in extreme events: The World Trade Center attacks, September 11, 2001. Natural Hazards, 39(2), 309-327.

Ditterich, R. G., Moysés, S. T., \& Moysés, S. J. (2012). O uso de contratos de gestão e incentivos profissionais no setor público de saúde. Cadernos de Saúde Pública, 28(4), 615-625.

Ebrahim, A. (2003). Accountability in practice: Mechanisms for NGOs. World Development, 31(5), 813-829.

Flora, P., \& Heidenheimer, A. J. (1981). The development of welfare states in Europe and America. Piscataway, Nova Jersey, USA: Transaction Publishers.

Frumkin, P. (2002). On being nonprofit: A conceptual and policy primer. Massachussets, USA: Harvard University Press.

Gomes, E. G. M. (2015). Conselhos gestores de políticas públicas: aspectos teóricos sobre o potencial de controle social democrático e eficiente. Cadernos EBAPE.BR, 13(4), 894-909.

Henderson, A. (2014). The Critical Role of StreetLevel Bureaucrats in Disaster and Crisis. In R. Schwester. (Ed.), Handbook of Critical Incident Analysis (pp. 217-235). Nova York, NY: M. E. Sharpe.

Instituto Brasileiro de Geografia e Estatística. (2016). As Fundações Privadas e Associações sem Fins Lucrativos no Brasil - 2016. Rio de Janeiro, RJ: Author. Retrieved from https://sidra.ibge.gov.br/ tabela/6914\#resultado

Instituto de Pesquisa Econômica Aplicada. (2020). Mapa de Organizações da Sociedade Civil. Rio de Janeiro, RJ: Author. Retrieved from https://mapaosc. ipea.gov.br/resultado-consulta.html 
James, E. (1990). Economic theories of the nonprofit sector: A comparative perspective. In H. K. Anheier \& W. Seibel, The Third Sector, Comparative Studies of Non-Profit Organizations (Series De Gruyter Studies in Organization, 21, pp. 21-30). New York, NY: The Gruyter.

Kang, M., Kim, J. R., \& Cha, H. (2018). From concerned citizens to activists: a case study of 2015 South Korean MERS outbreak and the role of dialogic government communication and citizens' emotions on public activism. Journal of Public Relations Research, 30(5-6), 202-229.

Lecy, J. D., \& Van Slyke, D. M. (2012). Nonprofit sector growth and density: testing theories of government support. Journal of Public Administration Research and Theory, 23(1), 189-214.

Lin, T. H. (2015). Governing natural disasters: state capacity, democracy, and human vulnerability. Social Forces, 93(3), 1267-1300.

Marchesini da Costa, M. (2017). Assessing Government-Nonprofit Collaborations and Nonprofit Density in Brazil. Revista de Administração Pública, 51(3), 330-347.

Marchesini da Costa, M. (2019). Paths for improving non-profit impact on society: lessons from government-non-profit relationships in Brazil. Development in Practice, 29(3), 300-313.

Marcondes, M. M, Sandim, T. L., \& Diniz, A. P. R. (2018, January-March). Transversalidade e Intersetorialidade: mapeamento do debate conceitual no cenário brasileiro. Administração Pública e Gestão Social, 10(1), 1-73.

Mendonça, P. M. E., Alves, M. A., \& Nogueira, F. A. (2013). Arquitetura institucional de apoio às organizações da sociedade civil no Brasil: relatório final eixo Investimento Social Privado corporativo. São Paulo, SP: FGV.https://www.cdes.gov.br/jspui/ bitstream/11451/1019/1/rf_invest_social_priv_corp. pdf

Mendonça, P., Alves, M. A., \& Nogueira, F. (2016). Civil society organisations and the fight for rights in Brazil: analysis of an evolving context and future challenges. Development in Practice, 26(5), 592-605.

Moreira, J. N., Teodósio, A. S. S., \& Ayres, L. C. (2020). Participação das Organizações da Sociedade Civil nas Políticas Públicas Locais: a experiência do Movimento Nossa BH. Perspectivas em Políticas Públicas, 12(24), 109-142.

Najam, A. (2000). The Four C's of Government Third Sector-Government Relations. Nonprofit Management and Leadership, 10(4), 375-396.

O’Donovan, K. (2019). Disaster recovery service delivery: Toward a theory of simultaneous government and voluntary sector failures. Administration \& Society, 51(1), 120-139.

Offe, C. (1984). Dominação de classe e sistema político. Sobre a seletividade das instituições políticas. In C. Offe. (Ed.), Problemas Estruturais Do Estado Capitalista (pp. 140-177). Rio de Janeiro, RJ: Tempo Brasileiro.

Pagotto, L. M., Belinky, A., Macedo, F., \& Yamahaki, C. (2016). Entre o público e o privado: caminhos do alinhamento entre o investimento social privado e o negócio. São Paulo, SP: FGV.

Peci, A., Oquendo, M. I., \& Mendonça, P. (2020). Collaboration, (dis) trust and control in Brazilian manufactured public/non-profit partnerships. Voluntas, 31, 375-389.

Ribeiro, A. C., Andion, C., \& Burigo, F. (2015). Ação coletiva e coprodução para o desenvolvimento rural: um estudo de caso do Colegiado de Desenvolvimento Territorial da Serra Catarinense. Revista de Administração Pública, 49(1), 119-140.

Salamon, L. M. (1987). Of market failure, voluntary failure, and third-party government: Toward a theory of government-nonprofit relations in the modern welfare state. Nonprofit and Voluntary Sector Quarterly, 16(1-2), 29-49.

Salamon, L. M. (1995). Partners in public service: government-nonprofit relations in the modern welfare state. Baltimore, Maryland: John Hopkins Press.

Salamon, L. M., \& Anheier, H. K. (1998). Social origins of civil society: Explaining the nonprofit sector cross-nationally. Voluntas, 9(3), 213-248.

Shaw, R., \& Goda, K. (2004). From disaster to sustainable civil society: the Kobe experience. Disasters, 28(1), 16-40.

Simo, G., \& Bies, A. L. (2007). The role of nonprofits in disaster response: An expanded model of crosssector collaboration. Public Administration Review, 67(s1), 125-142. 
Smillie, I. (1995). The Alms bazaar: altruism under fire; non-profit organizations and international development. London, UK: Intermediation Technology Publications.

Smith, S. R., \& Lipsky, M. (1993). Nonprofit for hire: the Welfare State in the age of contracting. Cambridge, MA: Harvard University Press.

Souza, A. G., \& Oliveira. (2020). De Prestadora de Serviços à Parceira? Como Representantes de OSCs Atuantes na Defesa de Direitos percebem a Lei ${ }^{\circ}$ 13.019/2014. In: A. R. Leichsenring, A. L. Souza, L. Oliveira, L. Vilas Boas, P. Mendonça, A. Viotto \& T. Donnini. (Eds.), Marco Regulatório das Organizações da Sociedade Civil: Visões sobre os primeiros anos de vigência da Lei $n^{\circ}$ 13.019/2014. São Paulo, SP: FGV.

Steinberg, R. (2003). Economic theories of nonprofit organizations. In H. K. Anheier \& A. Ben-Ner, The study of nonprofit enterprise: Theories and approaches. New York, NY: Springer US.
Tilly, C. (2008). Credit and blame. Princeton, Nova Jersey, USA: Princeton University Press.

Titmuss, R. M. (1974). Social policy: An introduction. Crows Nest, Austrália: Allen and Unwin.

Waugh, W. L., Jr., \& Streib, G. (2006). Collaboration and leadership for effective emergency management. Public Administration Review, 66, 131-140.

Waugh, W. L., Jr., \& Sylves, R. T. (2002). Organizing the war on terrorism. Public Administration Review, $62,145-153$.

Weisbrod, B. (1978). The Voluntary Nonprofit Sector. Lanham, Maryland: Lexington Books.

Young, D. R. (2000). Alternative models of government-nonprofit sector relations: Theoretical and international perspectives. Nonprofit and Voluntary Sector Quarterly, 29(1), 149-172.

\section{Mário Aquino Alves}

https://orcid.org/0000-0002-6819-2585

Associate Professor at Fundação Getulio Vargas School of Business Administration in São Paulo (FGV EAESP). E-mail: Mario.Alves@fgv.br

\section{Marcelo Marchesini da Costa}

https://orcid.org/0000-0002-7039-6923

Assistant Professor at Insper Institute of Education and Research (Insper).E-mail: marcelomc5@insper.edu.br 